\title{
EVALUATION OF THE SYMBIOTIC EFFECTIVENESS OF PEA (Pisum sativum L.) GENOTYPES IN POT EXPERIMENT
}

\author{
V.A. ZHUKOV1, G.A. AKHTEMOVA', A.I. ZHERNAKOV1, A.S. SULIMA1, \\ O.Yu. SHTARK ${ }^{1}$, I.A. TIKHONOVICH'1, 2
}

\author{
${ }^{1}$ All-Russian Research Institute for Agricultural Microbiology, Federal Agency of Scientific Organizations, 3, sh. Pod- \\ bel'skogo, St. Petersburg, 196608 Russia,e-mail zhukoff01@yahoo.com, VZhukov@ARRIAM.ru (corresponding \\ author); \\ ${ }^{2}$ Saint-Petersburg State University, 7/9, Universitetskaya nab., St. Petersburg, 199034 Russia \\ ORCID: \\ Zhukov V.A. orcid.org/0000-0002-2411-9191 \\ Akhtemova G.A. orcid.org/0000-0001-7957-3693 \\ Zhernakov A.I. orcid.org/0000-0001-8961-9317 \\ Sulima A.S. orcid.org/0000-0002-2300-857X \\ Shtark O.Y. orcid.org/0000-0002-3656-4559 \\ The authors declare no conflict of interests \\ Acknowledgements: \\ Supported by Russian Science Foundation (grant № 16-16-00118) \\ Received October 12, 2016 \\ Tikhonovich I.A. orcid.org/0000-0001-8968-854X
}

\section{Abstract}

The successful use of plant-microbe systems based on legumes in agriculture requires creation of new cultivars of crop legumes effectively interacting with microbes. For the selection of cultivars of crop legumes, the effectiveness of interaction with beneficial soil microorganisms (EIBSM) trait has been proposed. EIBSM is estimated as a percentage of increment in a number of agriculturally important parameters (plant biomass, number and total biomass of seeds, as well as weight of 1000 seeds) after applying the microbial inoculum compared to untreated control. The aim of this study was to evaluate the EIBSM trait in a pot experiment involving two pea ( $P i$ sum sativum L.) genotypes that have shown high and low effectiveness of interaction with beneficial soil microflora in a three-year field experiment. The highly effective in symbiosis with nodule bacteria and arbuscular-mycorrhizal fungi genotype k-8274 (France, cv. Vendevil) and ineffective genotype k-3358 (Saratov region, Russia) from the VIR Collection of cultivated peas of N.I. Vavilov All-Russian Institute of Plant Genetic Resources were used in the study. Plants were grown during the summer season of 2012 in a greenhouse in the 5-liter pots on sod-podzolic light loamy soil. Treatment variants were as follows: control (untreated soil); nodule bacteria + arbuscular mycorrhizal fungi (NB + AMF); nodule bacteria (NB); mineral nutrition (NPK). Variants of soil moisture were as follows: low moisture (watering with $30 \%$ of full moisture capacity, FMC) and optimal moisture (watering with $60 \%$ of FMC). Mineral fertilizers (NPK) were applied in the form of pure salts in a dose of $0.1 \mathrm{mg}$ a.i. per $1 \mathrm{~kg}$ of soil. For NB inoculation, the effective strain Rhizobium leguminosarum bv. viciae RCAM1026 was used. AM fungi for inoculation were propagated on the sorghum (Sorghum sp.) roots. A mixed inoculum containing three AMF isolates, Rhizophagus irregularis (syn. Glomus intraradices) RCAM8 (= BEG144), R. irregularis BEG53 and Glomus sp. ST3, was applied. Samples were gathered at the budding stage, after 1 month of vegetation (to determine the amount of nodules and the dry plant biomass) and at the end of vegetation about 3 months after planting (to determine the dry plant biomass, seed weight and amount). When grown in pots, highly effective and ineffective genotypes demonstrated the expected differences in EIBSM. The dry weight after 1 month of vegetation of highly effective k-8274 genotype showed a statistically significant increase in the NB and NPK variants compared to the control. At the same time, this parameter in the ineffective genotype k-3358 significantly increased only under the influence of mineral nutrition, but not nodule bacteria. Also, under treatment of NB, k8274 genotype increased 1000 seed weight, while in k-3358 under the same treatment this parameter was slightly decreased. Statistically significant negative effect of low soil moisture on all estimated parameters in k-3358 genotype and the majority of the estimated parameters in k-8274 genotype was also revealed. Thus, the plants grown in the pot experiment are equivalent to the material grown in the field, and therefore can be used to determine physiological and biochemical markers of functioning of symbiotic systems in order to identify the molecular basis of EIBSM trait. For modeling the pea EIBSM trait in a pot experiments it is recommended to use at least 6 replicas for each genotype. Also, it is necessary to carefully control the soil moisture.

Keywords: legume-rhizobial symbiosis, arbuscular mycorrhiza, symbiotic effectiveness, 
To minimize the chemical impact on the environment (reducing application of chemical fertilizers and agents for protection against pathogens) $[1,2]$ and the adverse effect of environmental factors (unfavorable weather conditions, impact of pathogens, etc.) [3), it is advisable to use microbilogical preparations, for example, those based on nodule bacteria or arbuscular mycorrhizal fungi that have positive influence on plants $[4,5]$. There are also preparations containing a complex of beneficial soil microorganisms $[6,7)$.

Legume plants are crops suitable for cultivation within the modern concept of adaptive plant growing that was shown for lentils [8], soya [9], peas [10, 11], beans [12, 13], chickpeas [14], and other legumes [15-17]. The successful use of plant-microbe systems based on legumes requires creation of entirely new cultivars capable of effectively interacting with beneficial soil microorganisms $[17,18]$. One of the methods to achieve the purpose is to mobilize plant genetic resources, i.e. search for valuable gene alleles that can improve symbiotic properties and height parameters of a plant when introducing into a genotype.

The nitrogen fixation effectiveness trait is traditionally used when selecting legume crops for the increased symbiotic potential [19-21]. It has also been proposed to consider the integral trait of the effectiveness of interactions with beneficial soil microorganisms (EIBSM) [17, 22] which is estimated as an increment in a number of economically important parameters (plant biomass, seed number and total weight, as well as weight of 1000 seeds) after applying microbiological preparations as compared to untreated control. Earlier, the field experiments on 25 pea genotypes allowed estimating EIBSM variability and identifying contrast genotypes (highly effective and ineffective when interacting with beneficial soil microorganisms) [10, 12].

In this work, we have considered for the first time the possibility of EIBSM modelling in a pot experiment as well as assessed the impact of soil moisture content on the trait emergence.

The aim of the study was to evaluate the effectiveness of interactions of two pea genotypes (that had shown high and low effectiveness in a field experiment) with beneficial soil microorganisms in the model pot experiment.

Technique. The highly effective in symbiosis with nodule bacteria k-8274 genotype (France, Vendevil cultivar) and ineffective k-3358 genotype (Saratov Province, Russia) of edible peas (Pisum sativum L.) from the VIR collection of cultivated peas (N.I. Vavilov All-Russian Institute of Plant Genetic Resources, St. Petersburg) were used in the study [23]. The plants were grown during the summer season of 2012, in greenhouses, in the 5-liter pots (3 plants in each pot) on sod-podzolic light loamy soil (Leningrad Province, area of Belogorka Science and Production Association), $\mathrm{C}_{\text {humus }} 1.27 \%$ and $\mathrm{N}_{\text {total }} 0.11 \%, \mathrm{pH}_{\text {salt }}$ 4.92. Agrochemical soil studies were conducted using generally accepted methods [24]. Calcium carbonate was used to chalk the soil.

Treatment variants were as follows: control (untreated soil); nodule bacteria + arbuscular mycorrhizal fungi $(\mathrm{NB}+\mathrm{AMF})$; nodule bacteria $(\mathrm{NB})$; mineral fertilizers (NPK). The effect of low (30\% of the full moisture capacity, FMC) and optimal (60\% of the FMC) moisture content was compared as well (there were 6 replicates for the optimal watering and 3 replicates for $30 \%$ FMC watering). Mineral fertilizers (NPK) were applied in the form of pure salts at a dose of $0.1 \mathrm{mg}$ of a.i. per $1 \mathrm{~kg}$ of soil $\left(\mathrm{N}_{0.1} \mathrm{P}_{0.1} \mathrm{~K}_{0.1}\right)$. Ammonium nitrate $\mathrm{NH}_{4} \mathrm{NO}_{3}$, monobasic calcium phosphate $\mathrm{Ca}\left(\mathrm{H}_{2} \mathrm{PO}_{4}\right)_{2} \cdot \mathrm{H}_{2} \mathrm{O}$, and potassium chloride $\mathrm{KCl}$ were applied. For the NB inoculation, the effective strain of $R h i$ zobium leguminosarum bv. viciae RCAM1026 from the collection of All-Russian 
Research Institute for Agricultural Microbiology was used [25, 26]. The bacteria were grown for 3 days with aeration in the liquid medium № $79\left(\mathrm{~K}_{2} \mathrm{HPO}_{4}\right.$ $0.5 \mathrm{~g} / \mathrm{l} ; \mathrm{MgSO}_{4} \cdot 7 \mathrm{H}_{2} \mathrm{O} 0.2 \mathrm{~g} / \mathrm{l} ; \mathrm{NaCl} 0.1 \mathrm{~g} / \mathrm{l} ; \mathrm{CaCO}_{3}$, traces; mannitol $10 \mathrm{~g} / \mathrm{l}$; yeastrel $0.4 \mathrm{~g} / \mathrm{l})$. Then, sterilized seeds of edible peas were added to the suspension of bacteria having $10^{7}-10^{8}$ cell titer and placed on a shaker for 12 hours [27, 28]. The mycorrhizal fungi for inoculation were propagated on sorghum (Sorghum sp.) roots in the soil mixed with washed filter cake (WFC) [6, 29]. A mixed inoculum contained three AMF isolates from the collection of AllRussian Research Institute for Agricultural Microbiology, the Rhizophagus irregularis (syn. Glomus intraradices) RCAM8 (= BEG144), R. irregularis BEG53 and Glomus sp. ST3. Before planting, the AMF inoculum was mixed with soil in the amount of $20 \mathrm{~g}$ per a pot, and $1.5 \mathrm{~g}$ of inoculum was added under each pea seed.

Plants were sampled at budding-blooming after 1 month of vegetation (to count the number of nodules and determine the dry plant weight) and at the end of vegetation about 3 months after planting (to determine the dry plant weight, seed weight and number).

Statistical processing was carried out in SigmaPlot 12.0 (Systat Software, USA). The effect of moisture and treatment factors on the traits was assessed by the two-way analysis of variance for each genotype. The Student's $t$-test was used to compare treatment variants to each other. The weight of 1000 seeds calculated as (weight of plant seeds/number of plant seeds) $\times 1000$ was estimated using the nonparametric Mann-Whitney U-test.

Results. The two-way analysis of variance has revealed the statistically significant negative effect of the low soil moisture on all estimated parameters in ineffective k-3358 genotype and the majority of those in highly effective k-8274 genotype (Table, Fig.).

Effect of various factors and their interactions on productivity parameters in pea (Pisum sativum L.) genotypes under optimal and insufficient moisture conditions, when treated (NB, NB + AMF, NPK) and untreated (two-way analysis of variance)

\begin{tabular}{|c|c|c|c|c|c|c|}
\hline \multirow{2}{*}{ Genotype } & \multirow{2}{*}{ Factor } & \multicolumn{2}{|c|}{ Aboveground dry biomass } & \multicolumn{2}{|c|}{ Seeds } & \multirow{2}{*}{$\begin{array}{l}\text { Number } \\
\text { of nodules }\end{array}$} \\
\hline & & in 1 month & in 3 months & number & weight & \\
\hline \multirow[t]{3}{*}{$\mathrm{k}-8274$} & Moisture content & 0.347 & $<0.001^{*}$ & $<0.001^{*}$ & $<0.001^{*}$ & 0.107 \\
\hline & Treatment & $0.004^{*}$ & $0.010^{*}$ & $0.005^{*}$ & $0.034^{*}$ & $<0.001^{*}$ \\
\hline & Interaction of the two factors & 0.809 & 0.090 & 0.354 & 0.073 & $0.002 *$ \\
\hline \multirow[t]{3}{*}{$\mathrm{k}-3358$} & Moisture content & $<0.001^{*}$ & $<0.001^{*}$ & $<0.001^{*}$ & $<0.001^{*}$ & $0.011^{*}$ \\
\hline & Treatment & $<0.001^{*}$ & 0.0770 & 0.243 & 0.291 & $<0.001^{*}$ \\
\hline & Interaction of the two factors & 0.118 & 0.076 & 0.212 & 0.248 & $0.025^{*}$ \\
\hline \multicolumn{7}{|c|}{$\begin{array}{l}\text { No t e. Optimal and insufficient moisture content is } 60 \text { and } 30 \% \text { of the full moisture capacity, respectively; } \\
\text { NB }- \text { nodule bacteria Rhizobium leguminosarum bv. Viciae RCAM1026; AMF - arbuscular mycorrhizal fungi, } \\
\text { mixed inoculum of Rhizophagus irregularis (syn. Glomus intraradices) RCAM8 (= BEG144), R. irregularis } \\
\text { BEG53 and Glomus sp. ST3; NPK }-\mathrm{N}_{0.1} \mathrm{P}_{0.1} \mathrm{~K}_{0.1} \text {. P-values reflecting the significance of each factor and interac- } \\
\text { tion of two factors provided. } \\
* \mathrm{P}<0.05 \text {. }\end{array}$} \\
\hline
\end{tabular}

At the same time, the treatment variant had no expressed effect (see Table, Fig.). Therefore, EIBSM in limited volume pots was strongly affected by the soil moisture that surpassed the impact of symbiotic microorganisms and mineral fertilizers.

At the low moisture, the aboveground dry biomass of k-8274 plants gathered in 1 month of vegetation did not change depending on the treatment variant (see Fig., A). The significant gain in biomass in the NB and NPK variants as compared to the control was observed under the optimal moisture conditions. As for $\mathrm{k}-3358$, the estimated parameter did not change in the lack of moisture, and the significant gain was revealed at the optimal moisture when treated with mineral fertilizers, but not nodule bacteria. 

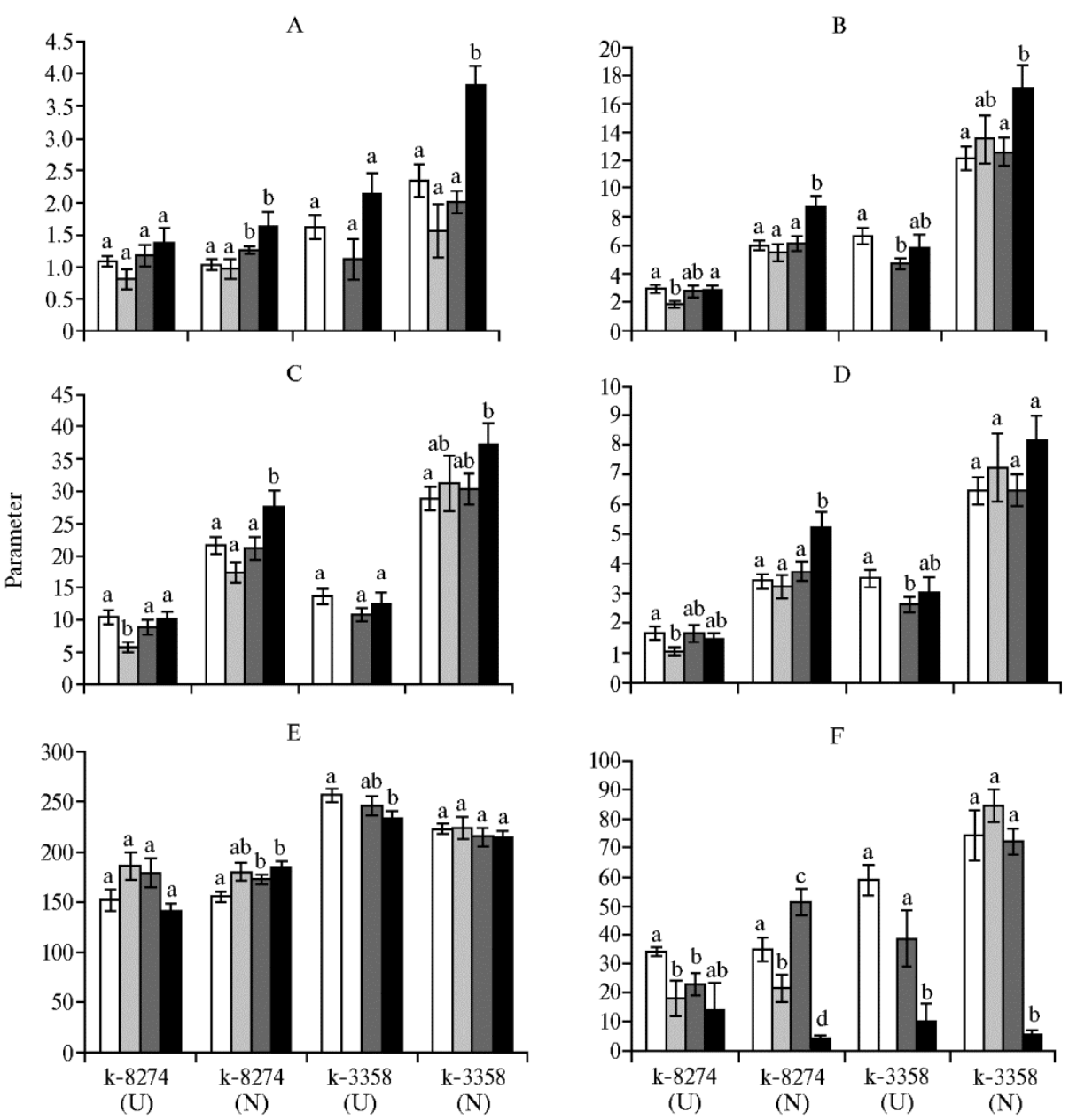

Aboveground dry biomass of plants in 1 (A) and 3 months of vegetation (B), g; number of plant seeds, pcs $(C)$; seed weight per plant, $g(D) ; 1000$ seed weight, $g(E)$; number of nodules, pcs $(F)$ in pea (Pisum sativum L.) genotypes k-8274 (highly effective when interacting with beneficial soil microorganisms in the field experiment) and k-3358 (ineffective) at various soil moisture and different treatment variants: 1 - control (untreated soil), 2 - nodule bacteria + arbuscular-mycorrhizal fungi $(\mathrm{NB}+\mathrm{AMF}), 3-\mathrm{NB}, 4-$ mineral fertilizers $(\mathrm{NPK})$. $\mathrm{U}-$ insufficient soil moisture, $\mathrm{N}-$ optimal soil moisture. No available data on NB + AMF variant for k-3358 under the insufficient moisture conditions. The lettered values $(\mathrm{a}, \mathrm{b}, \mathrm{c}, \mathrm{d})$ have statistically significant $(\mathrm{P}<0.05)$ differences within a single treatment variant ( $a$ differs from $b$, and $a b$ does not differ from a and does not differ from $b$ ).

The low moisture amplified the effects of NB + AMF treatment on the aboveground dry biomass of k-8274 genotype plants gathered upon completion of vegetation (see Fig., B). No data on this treatment variant was available for k3358. Probably, the formation and support of the arbuscular mycorrhizal symbiosis under the moisture deficit in a confined pot volume were energetically unfavorable for the plants. The NB treatment against the low moisture resulted in the decrease of k-3358 plant biomass that evidenced of its low effectiveness when interacting with symbionts. In the optimal moisture conditions, the statistical significance was characteristic of mineral fertilizers, but not the treatment with microorganisms. Perhaps, the positive effect of microorganisms was abolished during long vegetation due to the stress experienced by plants because of limited volume pots.

The number of seeds of k-8274 (see Fig., C) decreased in the NB + AMF 
variant under the low moisture. The treatment with NB only had no considerable impact on the parameter in both genotypes at either optimal or low moisture. The positive effect of mineral fertilizers was noted for k-8274 and k-3358 at the optimal moisture, but not when there was a lack of moisture.

The NB + AMF treatment had adverse effect on the weight of seeds for k-8274 genotype (see Fig., D) in the low moisture conditions. The same effect was observed when treating k-3358 seeds with NB at moisture deficiency. The weight of seeds increased only due to mineral fertilizers applied at the optimal soil moisture.

The 1000 seed weight in k-8274 genotype did not depend on the control moisture and, however, increased when treating with NB (statistically significant only in the optimal moisture conditions) (see Fig., E). For k-3358 genotype, the 1000 seed weight, to the contrary, decreased slightly after the NB treatment (statistically significant in the lack of moisture conditions). It is consistent with the results of field experiments where the weight of 1000 seeds increased after treatment with microbiological preparations in the highly effective genotypes and did not change or decreased slightly in the ineffective ones [10, 22].

The application of mineral fertilizers had adverse effects on the number of nodules (see Fig., F) that was associated with activation of autoregulation systems (negative control over the energy-consuming nodule formation when there was sufficient amount of bound nitrogen in soil) [30, 31]. The lack of moisture led to decreased number of nodules in k-3358 genotype in any treatments. The $\mathrm{NB}$ inoculation (including NB $+\mathrm{AMF}$ ) against the lack of moisture inhibited the nodule formation in both genotypes because of autoregulation. The optimal moisture variant showed the decrease in the number of nodules in k-8274 genotype in case of NB + AMF that was probably associated with the operation of common autoregulation system of nodular and arbuscular mycorrhizal symbioses [30-32]. The number of nodules when using only NB was higher in k-8274 compared to the untreated control that may be a genetically reduced ability for the nodule formation in this genotype.

Thus, the pea genotypes which showed the high and low effectiveness when interacting with nodule bacteria in the field experiments had similar differences in the greenhouse trial. For example, the statistically significant gain in plant biomasses 1 month after planting and in 1000 seed weight, when inoculated with nodule bacteria (as compared to the non-inoculated control), was observed only in highly effective k-8274 genotype, while ineffective k-3358 genotype demonstrated no positive relation with inoculation by these parameters. On the contrary, the weight of plant seeds when inoculated with nodule bacteria in the insufficient moisture conditions decreased significantly as compared to the non-inoculated control. Hence, still unknown genetic programs underlying EIBSM are implemented similarly in pot experiments and under field conditions. The material grown in the pot experiment is equivalent to that obtained in field and may be used to identify molecular underpinnings of genetic control of EIBSM trait through the transcriptomic sequencing.

So, for modeling the integral EIBSM trait (effectiveness of interactions with beneficial soil microorganisms) in peas in pot experiments, at least 6 replicates for each genotype should be used. It is also necessary to control the soil moisture since the drought stress masks the beneficial action of microorganisms reducing differences between the highly effective and ineffective genotypes. The budding-blooming stage at which first distinctions between genotypes are noted can be recommended to collect materials for analyzing differential expression of genes, enzymatic activity and identifying other physiological and biochemical markers of symbiotic system functioning. 


\section{REFERENCES}

1. B eddingto n J. Food security: contributions from science to a new and greener revolution. Philosophical Transactions of the Royal Society of London B: Biological Sciences, 2010, 365(1537): 61-71 (doi: 10.1098/rstb.2009.0201).

2. O' C a ll a g h a n M. Microbial inoculation of seed for improved crop performance: issues and opportunities. Appl. Microbial. Biot., 2016, 100(13): 5729-5746 (doi: 10.1007/s00253-016-7590-9).

3. FAOSTAT 2014. Food and Agriculture Organization of the United Nations. Available www.faostat.fao.org. No date.

4. Handbook of microbial biofertilizers. M.K. Rai (ed.). Haworth Press Technology Engineering, 2006.

5. IJ d o M., C rane nbrou ck S., D e c le r ck S. Methods for large-scale production of AM fungi: past, present, and future. Mycorrhiza, 2011, 21: 1-16 (doi: 10.1007/s00572-010-0337-z).

6. Che botar' V.K., N a m k i n a T.S., B orisov A.Yu. Kompleksnoe mikrobnoe udobrenie «BisolbiMiks»: fundamental'nye osnovy, sposoby proizvodstva i primeneniya, naznachenie [BisolbiMix, a complex bacterial fertilizer: fundamentals, production, and application]. A.Yu. Borisov (ed.). St. Petersburg, 2015 (in Russ.).

7. Shtark O., Kumari S., Singh R., Sulima A., Akhtemova G., Zhukov V., Shcherbakov A., Shcherbakova E., Adholeya A., Borisov A. Advances and prospects for development of multi-component microbial inoculant for legumes. Legume Perspectives, 2015, 8: 40-44.

8. Xavier L.J.C., Germida J.J. Response of lentil under controlled conditions to coinoculation with arbuscular mycorrhizal fungi and rhizobia varying in efficacy. Soil Biol. Biochem., 2002, 34(2): 181-188 (doi: 10.1016/S0038-0717(01)00165-1).

9. Labutova N.M., Polyakov A.I., Lyakh V.A., Gordon V.L. Doklady RASKhN, 2004, 4(2): 2-4 (in Russ.).

10. Shtark O.Yu., Danilova T.N., Naumkina T.S., Vasil'chikov A.G., Chebot a r' V.K., Kazakov A.E., Zhernakov A.I., Ne mankin T.A., Prile pskaya N.A., Borisov A.Yu., Tikhonovich I.A. Ekologicheskaya genetika, 2006, 4(2): 22-28 (in Russ.).

11. D a nilova T.N. Effektivnost' vzaimodeistviya gorokha (Pisum sativum L.) s kompleksom poleznoi pochvennoi mikroflory. Novyi priznak selektsii zernobobovykh kul'tur. Avtoreferat kandidatskoi dissertatsii [Efficacy of pea (Pisum sativum L.) interaction with useful soil microflora: a new sign for legume breeding. PhD Thesis]. St. Petersburg, 2011 (in Russ.).

12. P a rakhin N.V., $\mathrm{N}$ a u $\mathrm{m} k$ i n a T.S., O s i n A.A., O s i n a V.S. Vestnik orlovskogo gosudarstvennogo agrarnogo universiteta, 2008, 4: 2-4 (in Russ.).

13. Naumkina T.S., Suvorova G.N., Vasil'chikov A.G., Miroshnikova M.P., B arbashov M.V., Donskaya M.V., Donskoi M.M., Gromova T.A., $\mathrm{N}$ a u $\mathrm{m}$ k i n V.V. Zernobobovye $i$ krupyanye kul'tury, 2012, 2: 21-26 (in Russ.).

14. L o b k ov V.T., D o n s k y a M.V., V a s i l' $\mathrm{ch}$ i k o v A.G. Vestnik orlovskogo gosudarstvennogo agrarnogo universiteta, 2011, 30(3): 39-43 (in Russ.).

15. Lüscher A., Mu eller-Ha rvey I., Soussana J.F., Rees R.M., Pey raud J.L. Potential of legume-based grassland-livestock systems in Europe: a review. Grass Forage Sci., 2014, 69(2): 206-228 (doi: 10.1111/gfs.12124).

16. Oldroyd G.E.D., Dix on R. Biotechnological solutions to the nitrogen problem. Curr. Opin. Biotech., 2014, 26: 19-24 (doi: 10.1016/j.copbio.2013.08.006).

17. Sht ark O.Yu., Zhukov V.A., Suli ma A.S., S ingkh R., Naumkina T.S., Akh t e mova G.A., B orisov A.Yu. Ekologicheskaya genetika, 2015, 13(1): 33-46 (doi: 10.17816/ecogen13133-46) (in Russ.).

18. Zhuk ov V.A., Sht a rk O.Y., B orisov A.Y., Tikhonovich I.A. Breeding to improve symbiotic effectiveness of legumes. In: Plant breeding from laboratories to fields. S.B. Andersen (ed.). Rijeka, 2013: 167-207.

19. Grah a m P.H., H ung ria M., T lusty B. Breeding for better nitrogen fixation in grain legumes: where do the rhizobia fit in? Crop Management, 2004 (doi: 10.1094/CM2004-0301-02-RV).

20. Re nge 1 Z. Breeding for better symbiosis. Plant Soil, 2002, 245: 147-162 (doi: 10.1023/A:1020692715291).

21. Sidorova K.K., Go n charova A.V., Go ncharov P.L., S H u m ny i V.K. Selection of pea on rising of nitrogen fixation with the use of symbiotic mutants. Agricultural Biology, 2012, 1: 105-109 (doi: 10.15389/agrobiology.2012.1.105eng).

22. Shtark O.Y., B orisov A.Y., Zhuk ov V.A., Tikhonovich I.A. Mutually beneficial legume symbioses with soil microbes and their potential for plant production. Symbiosis, 2012, 57(3): 51-62 (doi: 10.1007/s13199-013-0226-2).

23. B o r i sov A.Yu., T S y g n o v V.E., S ht a rk O.Yu., Yakobi L.M., Na u m i $\mathrm{n}$ a T.S., S e r d y u k V.P., V i s h n a k o v a M.A. Gorokh (Simbioticheskaya effektivnost'): Katalog mirovoi kollektsii VIR [Pea: symbiotic effectiveness (VIR World Collection Catalog]. I.A. Tikhonovich, M.A. Vishnyakova (eds.). St. Petersburg, 2002, iss. 728 (in Russ.). 
24. Agrokhimicheskie metody issledovaniya pochv [Agrochemical analysis of soils]. A.V. Sokolov (ed.). Moscow, 1975.

25. Safronova V.I., Novikova N.I. Comparison of two methods for root nodule bacteria preservation: lyophilization and liquid nitrogen freezing. J. Microbial. Meth., 1996, 24(3): 231237 (doi: 10.1016/0167-7012(95)00042-9).

26. A f o n in A., S u li m a A., Z h e r n a k ov A., Z h u k o v V. Draft genome of the strain RCAM1026 Rhizobium leguminosarum bv. viciae. Genomics Data, 2017, 11: 85-86 (doi: 10.1016/j.gdata.2016.12.003).

27. B orisov A.Yu., Rozov S.M., Tsyganov V.E., Kulikova O.A., Kolyche va A.N., Yakobi L.M., Ovtsyna A.O., Tikhonovich I.A. Genetika, 1994, 30(11): 1484-1494 (in Russ.).

28. Tsyganov V.E., Voroshilova V.A., Kukalev A.S., Yakobi L.M., Azarova T.S., B orisov A.Yu., Tikho novi ch I.A. Genetika, 1999, 35(3): 352-360 (in Russ.).

29. Akhtemova G.A., Pershina E.V., Pinaev A.G., Andronov E.E., Shtark O.Yu., Chebotar' V.K., Borisov A.Yu., Tikhonovich I.A., Kiprushkina E.I., Abdurashitov S.F., Dzhianinazzi-Pirson V. Sakhar, 2010, 10: 30-36 (in Russ.).

30. O ka-Ki r a E., K a w a u c hi M. Long-distance signaling to control root nodule number. Curr. Opin. Plant Biol., 2006, 9(5): 496-502 (doi: 10.1016/j.pbi.2006.07.012).

31. Mortier V., Holsters M., Goormachtig S. Never too many? How legumes control nodule numbers. Plant, Cell \& Environment, 2012, 35(2): 245-258 (doi: 10.1111/j.13653040.2011.02406.x).

32. Shtark O.Yu., B or is ov A.Yu., Zhukov V.A., Nemankin T.A., Tikhonovi c h I.A. Ekologicheskaya genetika, 2011, 2: 80-94 (in Russ.). 